Зубілевич С. Я., к.е.н., професор (Національний університет водного господарства та природокористування, м. Рівне), Підгрушний В. А., студент (Національний університет водного господарства та природокористування, м. Рівне)

\title{
РОЗКРИТТЯ ІНФОРМАЦІЇ ПРО ВИПЛАТИ ПРАЦІВНИКАМ ОРГАНІВ МІСЦЕВОГО САМОВРЯДУВАННЯ В КОНТЕКСТІ ДЕЦЕНТРАЛІЗАЦІЇ ДЕРЖАВНИХ ФІНАНСІВ
}

На підставі дослідження категоріального апарату чинного законодавства, національних та міжнародних стандартів бухгалтерського обліку, точок зору науковців щодо сутності і функцій уточнено визначення виплат працівникам як об'єкта обліку і фінансової звітності на сучасному етапі реформування державного управління. 3апропонований підхід до поглиблення аналітики обліку виплат працівникам як найвагомішої статті витрат суб'єктів державного сектору з урахуванням потреб управління органом місцевого самоврядування та підзвітності громадськості. Одночасно обґрунтовано пропозиції щодо удосконалення аналітики обліку зобов'язань 3 виплат працівникам. Доповнено типовий план рахунків бухгалтерського обліку для відображення операцій з виплат працівникам. Розроблені рекомендації до розкриття виплат працівникам у фінансовій звітності, що підвищать якість інформації, яка надаватиметься внутрішнім та зовнішнім користувачам.

Ключові слова: виплати працівникам, управління державними фінансами, децентралізація, суб'єкт державного сектору, бухгалтерський облік, фінансова звітність.

Ефективне функціонування суб'єктів державного сектору, які виконують важливі суспільні функції управління, вкрай важливе для сучасного суспільства. Децентралізація фінансування та діяльності органів місцевого самоврядування продемонструвала чітку залежність формування місцевих бюджетів на $55 \%$ за рахунок податкових надходжень у вигляді податку на доходи фізичних осіб [1]. Це надає обґрунтоване право громадянам контролювати витрачання коштів, які спрямовані на забезпечення діяльності таких органів. Для цього створено єдиний веб-портал використання публічних коштів, портал «Відкритий бюджет»; фінансова звітність оприлюднюється на вебсайтах тощо. 
Однак інформація щодо формування грошової винагороди менеджерів громади - державних службовців та посадових осіб органів місцевого самоврядування залишається закритою. Водночас витрати на оплату праці $є$ основною статтею діяльності суб'єктів державного сектору і часто перевищують $80 \%$. У структурі валового внутрішнього продукту частка видатків на оплату праці в державному секторі у недалекій перспективі може сягнути $10 \%$ [2, С.14 ]. Така ситуація посилюватиме боргове навантаження країни.

Система оплати праці в державному секторі має бути реформована на засадах: кореляції якості та обсягу наданих послуг з обсягом витрат; планування фінансових ресурсів за результатом, а не видатками на утримання установи; формування кошторису від потреб споживачів публічних коштів; дієвої система внутрішнього та зовнішнього нагляду.

Інформаційне забезпечення усіх складових управління державними та місцевими фінансами формується в бухгалтерського обліку, який теж перебуває у стані реформування з метою відповідності сучасним потребам користувачів, та надається у вигляді бюджетної і фінансової звітності.

Аналіз останніх публікацій дав можливість з'ясувати, що відображення в обліку операцій з виплат працівникам суб'єктів підприємницького сектору знайшло належне відображення у наукових працях вітчизняних вчених. Зокрема, поняття, структура та особливості обліку виплат працівникам на основі аналізу МСБО та П(С)БО грунтовно вивчені В.С. Ленем, М.П. Штупун, Н.В. Овсюк та іншими. Питання розкриття інформації про виплати працівникам у фінансовій звітності розглядали К. Безверхий, Н.М. Воськало, І.В. Воськало.

Щодо суб'єктів державного сектору, то суть та облік заробітної плати їх працівників за новими НП(С)БОДС досліджували Н.М. Тополенко і А.М. Колеснікова, термінологічний аспект виплат працівникам та формування облікової політики - О.В. Кравченко, Л.П. Коритик, О.В. Клименко, В.С. Олійник та ін., розкриття інформації про виплати працівникам у примітках - 0.0. Яблонько.

Проте зазначені дослідження не повністю враховують останні процеси, що відбуваються в державному секторі: реформу управління державними фінансами; децентралізацію та зростання повноважень органів місцевого самоврядування; реформу оплати державних службовців; необхідність фінансової підзвітності суб'єктів державного сектору суспільству. Саме це і визначило мету даного дослідження - обґрунтування пропозицій щодо удосконалення обліку виплат працівникам суб'єктів державного сектору України та їх відображення у фінансовій звітності за НП(С)БОДС. Для досягнення цієї мети 
проведено аналіз змісту поняття виплат працівникам як об'єкта обліку в Україні, їх класифікації в умовах реформування системи управління держаними фінансами та розкриття у фінансових звітах.

Погоджуємося з авторами попередніх досліджень, що сучасна нормативно-правова база України містить поняття «виплати працівникам», «оплата праці», «заробітна плата». Причому сфери їх використання чітко розмежовані: бюджетний процес - видатки на оплату праці; трудове законодавство і статистика - оплата праці та заробітна плата; оподаткування - заробітна плата, додаткове благо; бухгалтерський облік і фінансова звітність - виплати працівникам. Проте прозора система обліку та звітності суб'єкта державного сектору повинна забезпечити або їх чіткий взаємозв'язок, або залишити для користування тільки ті, які відповідають сучасним реаліям. На наш погляд, більш сучасним поняттям є виплати працівникам, які, за визначенням МСБОДС 25, включають всі форми компенсації, що їх надає суб'єкт господарювання в обмін на послуги, надані працівниками [3]. В контексті МСБОДС поняття виплати працівникам є найширшим за змістом, і включає такі елементи операційних витрат, визначені НП(С)БОДС, як оплата праці та відрахування на соціальні заходи.

Спробуємо формалізувати особливі риси виплат працівникам суб'єктів державного сектору в сучасних умовах (табл. 1).

Таблиця 1

Характерні ознаки виплат працівникам суб'єкта державного сектору

\begin{tabular}{|l|l|}
\hline \multicolumn{1}{|c|}{ Ознака } & \multicolumn{1}{|c|}{ Характеристика ознаки } \\
\hline Визнання & З дати укладення трудового договору \\
\hline Джерело виплат & $\begin{array}{l}\text { Витрати/видатки(кошти загального або } \\
\text { спеціального фонду) }\end{array}$ \\
\hline $\begin{array}{l}\text { За що здійснюються випла- } \\
\text { ти }\end{array}$ & $\begin{array}{l}\text { За минулі та поточні послуги працівника } \\
\text { працедавцю }\end{array}$ \\
\hline $\begin{array}{l}\text { Суб'єкт, що здійснює випла- } \\
\text { ти }\end{array}$ & $\begin{array}{l}\text { Працедавець (суб'єкт державного сектору) } \\
\text { або третя особа }\end{array}$ \\
\hline Суб'єкт отримання виплат & $\begin{array}{l}\text { Працівник та/або члени його сім'ї, інші } \\
\text { утриманці }\end{array}$ \\
\hline $\begin{array}{l}\text { Періоди виплат (поточні та } \\
\text { довгострокові зобов'язання) }\end{array}$ & Поточні та майбутні \\
\hline $\begin{array}{l}\text { Суб'єкт визначення норма- } \\
\text { тивів виплат працівникам }\end{array}$ & Законодавство \\
\hline Форма виплат & Грошова та негрошова \\
\hline \multicolumn{1}{|c|}{ Складено авторами на підставі (4] } \\
\hline
\end{tabular}

Складено авторами на підставі [4]

Виплати працівникам в органах місцевого самоврядування, окрім Законів України «Про оплату праці», «Про відпустки», Кодексу 
законів про працю України, визначаються Законом України «Про службу в органах місцевого самоврядування» від 07.06.2001 № 2493III; постановою КМУ «Про упорядкування структури та умов оплати праці працівників апарату органів виконавчої влади, органів прокуратури, судів та інших органів» від 09.03.2006 № 268, з урахуванням останніх змін.

Зауважимо, що, починаючи з 01.01.15 р., будь-який орган місцевого самоврядування має право самостійно прийняти рішення щодо кількості посад у своєму штатному розписі, визначити обсяг видатків на оплату праці працівників [5]. Розглянемо склад виплат працівникам органу місцевого самоврядування на прикладі Бродівської районної ради (табл. 2).

Таблиця 2

Склад виплат працівникам Бродівської районної ради*

\begin{tabular}{|c|c|c|c|}
\hline \multicolumn{3}{|c|}{ Заробітна плата } & Виплати, що не на- \\
\hline Основна & Додаткова & Інші & лежать до ФОП \\
\hline $\begin{array}{l}\text { 1. Посадо- } \\
\text { вий } \\
\text { оклад }\end{array}$ & $\begin{array}{l}\text { 1. Доплата за } \\
\text { ранг; } \\
\text { 2. Доплата за } \\
\text { вислугу ро- } \\
\text { ків; } \\
\text { 3. Щорічна } \\
\text { відпустка; } \\
\text { 4. Надбавка за } \\
\text { інтенсивність }\end{array}$ & $\begin{array}{l}\text { 1. Матеріальна } \\
\text { допомога на } \\
\text { вирішення со- } \\
\text { ціально- } \\
\text { побутових пи- } \\
\text { тань; } \\
\text { 2. Матеріальна } \\
\text { допомога для } \\
\text { оздоровлення; } \\
\text { 3. Премії; } \\
\text { 4. Індексація }\end{array}$ & $\begin{array}{l}\text { 1. Допомога по } \\
\text { тимчасовій не- } \\
\text { працездатності; } \\
\text { 2. Суми вихідної } \\
\text { допомоги при } \\
\text { припиненні тру- } \\
\text { дового договору }\end{array}$ \\
\hline
\end{tabular}

Складено авторами

Конкретні умови, порядок та розміри преміювання працівників визначаються у положенні про преміювання відповідного органу. Так, у Бродівській районній раді встановлені такі види доплат і надбавок (табл. 3).

Таблиця 3

Доплати та надбавки до посадового окладу працівників Бродівської районної ради

\begin{tabular}{|c|c|c|c|c|c|c|c|}
\hline $\begin{array}{l}\text { № } \\
3 / \pi\end{array}$ & Назва посади & 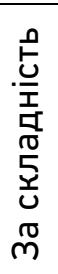 & 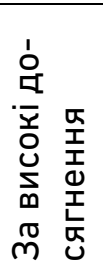 & 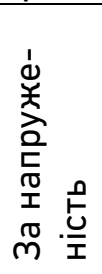 & 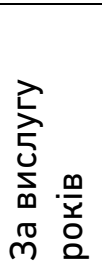 & 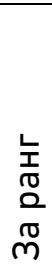 & 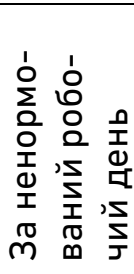 \\
\hline 1 & 2 & 3 & 4 & 5 & 6 & 7 & 8 \\
\hline 1. & Голова районної ради & + & + & + & + & + & \\
\hline
\end{tabular}


продовження табл. 3

\begin{tabular}{|c|c|c|c|c|c|c|c|}
\hline 2. & $\begin{array}{l}\text { Заступник голови район- } \\
\text { ної ради }\end{array}$ & & & + & + & + & \\
\hline 3. & Керуючий справами & + & + & + & + & + & \\
\hline 4. & $\begin{array}{l}\text { Референт-спеціаліст I ка- } \\
\text { тегорії }\end{array}$ & & + & & & & \\
\hline & \multicolumn{7}{|c|}{ Загальний відділ } \\
\hline 5. & Начальник відділу & & & + & + & + & \\
\hline 6. & $\begin{array}{l}\text { Радник } 3 \text { інформаційних } \\
\text { питань, протокольної ро- } \\
\text { боти та контролю }\end{array}$ & & & + & + & + & \\
\hline 7. & Радник з правових питань & & & + & + & + & \\
\hline \multirow[t]{2}{*}{8.} & Секретар керівника & + & & + & + & + & \\
\hline & \multicolumn{7}{|c|}{ Фінансово-господарський відділ } \\
\hline 9. & $\begin{array}{l}\text { Начальник відділу, голов- } \\
\text { ний бухгалтер }\end{array}$ & & + & + & + & + & \\
\hline 10. & $\begin{array}{l}\text { Радник з питань бюджету, } \\
\text { фінансів та економічної } \\
\text { реформи }\end{array}$ & & + & + & + & + & \\
\hline 11. & Водій I класу & & & + & & & + \\
\hline \multirow[t]{2}{*}{12.} & Сторож & + & & & & & + \\
\hline & \multicolumn{7}{|c|}{ Відділ комунального майна } \\
\hline 13. & Начальник відділу & & & + & + & + & \\
\hline 14. & $\begin{array}{l}\text { Радник з питань регулю- } \\
\text { вання земельних відно- } \\
\text { син, взаємодії з органами } \\
\text { державної виконавчої } \\
\text { влади та роботи із звер- } \\
\text { неннями громадян }\end{array}$ & & & + & + & + & \\
\hline 15. & Завідувач господарством & + & & + & & & + \\
\hline \multirow[t]{2}{*}{16.} & Прибиральниця & + & & + & & & + \\
\hline & \multicolumn{7}{|c|}{ Відділ районної ради у справах захисту прав громадян як споживачів } \\
\hline 17. & Начальник відділу & & & + & + & + & \\
\hline 18. & Головний спеціаліст & & & + & + & + & \\
\hline 19. & Водій & & & & & & + \\
\hline & PA30M & & & & & & 20 \\
\hline
\end{tabular}

Складено авторами 
Табл. 3 підтверджує думку фахівців Центру економічної стратегії [2], що сьогодні частка тимчасових компонентів виплат працівникам $€$ надто високою. Це робить службовця заручником керівника. Існує високий ризик перетворення премії з інструменту заохочення на інструмент тиску чи схиляння до корупції. Закон України «Про державну службу» [6] збільшив частку посадового окладу з 26\% у 2015 році до $34 \%$ у 2016 році, проте такий ії рівень ще не вважається достатнім. 31 січня 2019 року щоквартальні премії будуть обмежені $30 \%$ річного посадового окладу, а максимальний розмір преміального фонду не повинен буде перевищувати $20 \%$ річного фонду оплати праці.

Наразі економія фонду оплати праці повністю розподіляється на преміальні, що призводить до маніпуляцій керівників органів 3 вакантними посадами з метою збільшення ресурсів для виплат своїм підлеглим. Високим $€$ також рівень надбавки за вислугу років (до $50 \%)$, що фактично призводить до дискримінації молодих працівників.

Управління такими та іншими ризиками, які сьогодні існують в органах місцевого самоврядування, потребує відповідної інформації для їх оцінки та прийняття обґрунтованих і своєчасних рішень з їх зниження. Тому під час побудови номенклатури обліку виплат працівникам (табл. 4) слід керуватися таким:

- система бухгалтерського обліку є багатоцільовою та повинна забезпечити інформацією керівництво суб'єкта господарювання, головного розпорядника бюджетних коштів, контролюючі органи, громадськість;

- слід інтегрувати чинні вимоги до бюджетної та фінансової звітності;

- під час понесення виплат працівникам одночасно виникають витрати та поточні зобов'язання.

Таблиця 4

Ознаки класифікації, використані для побудови облікової номенклатури виплат працівникам Бродівської районної ради*

\begin{tabular}{|l|l|}
\hline $\begin{array}{l}\text { № } \\
\text { з/п }\end{array}$ & \multicolumn{1}{|c|}{ Групи ознак класифікації } \\
\hline 1 & Для потреб бюджетної звітності \\
\hline & - за кодами програмної класифікації \\
\hline & - за кодами економічної класифікації видатків \\
\hline & - за видами бюджетів \\
\hline & - за видами фондів бюджету \\
\hline
\end{tabular}


продовження табл. 4

\begin{tabular}{|l|l|}
\hline 2 & Для потреб управлінського обліку і внутрішнього контролю \\
\hline & - за складовими виплат працівникам \\
\hline & - за структурними підрозділами (центрами витрат) \\
\hline & - за категоріями персоналу (державні службовці, допоміж- \\
& ний та обслуговуючий персонал) \\
\hline & - за працівниками (табельний номер або ідентифікаційний \\
& код) \\
\hline 3 & - за формою виплат (готівкою, через карткові рахунки) \\
\hline & - Для потреб фінансової звітності \\
\hline & - за обмінними та необмінними операціями \\
\hline & - за елементами операційних витрат \\
& заборговтами обліку (витрати, кредиторська та дебіторська \\
\hline
\end{tabular}

Складено авторами

Наведені вище ознаки класифікації дозволили розробити робочий план рахунків з поглибленою аналітикою (табл. 5).

Публічний характер як самих органів-суб'єктів владних повноважень, так і їх посадових осіб вимагає оприлюднення певної інформації для формування громадської думки про довіру до влади та підтримку їі авторитету у суспільстві. Заробітна плата та інші виплати (преміі, матеріальна допомога тощо) посадовим та службовим особам є витратами з бюджету.

Законом України «Про доступ до публічної інформації» визначено [7], що доступ до інформації про розпорядження бюджетними коштами, володіння, користування чи розпорядження державним, комунальним майном, у тому числі до копій відповідних документів, умови отримання цих коштів чи майна, прізвища, імена, по батькові фізичних осіб та найменування юридичних осіб, які отримали ці кошти або майно, не може бути обмежено.

Відповідно до Закону України «Про запобігання і протидію корупції» [8] інформація про розміри, види оплати праці та будь-які інші виплати з бюджету особам, уповноваженим на виконання функцій держави або місцевого самоврядування, не може бути віднесена до інформації з обмеженим доступом. 
Витяг з робочого плану рахунків бухгалтерського обліку

Бродівської районної ради

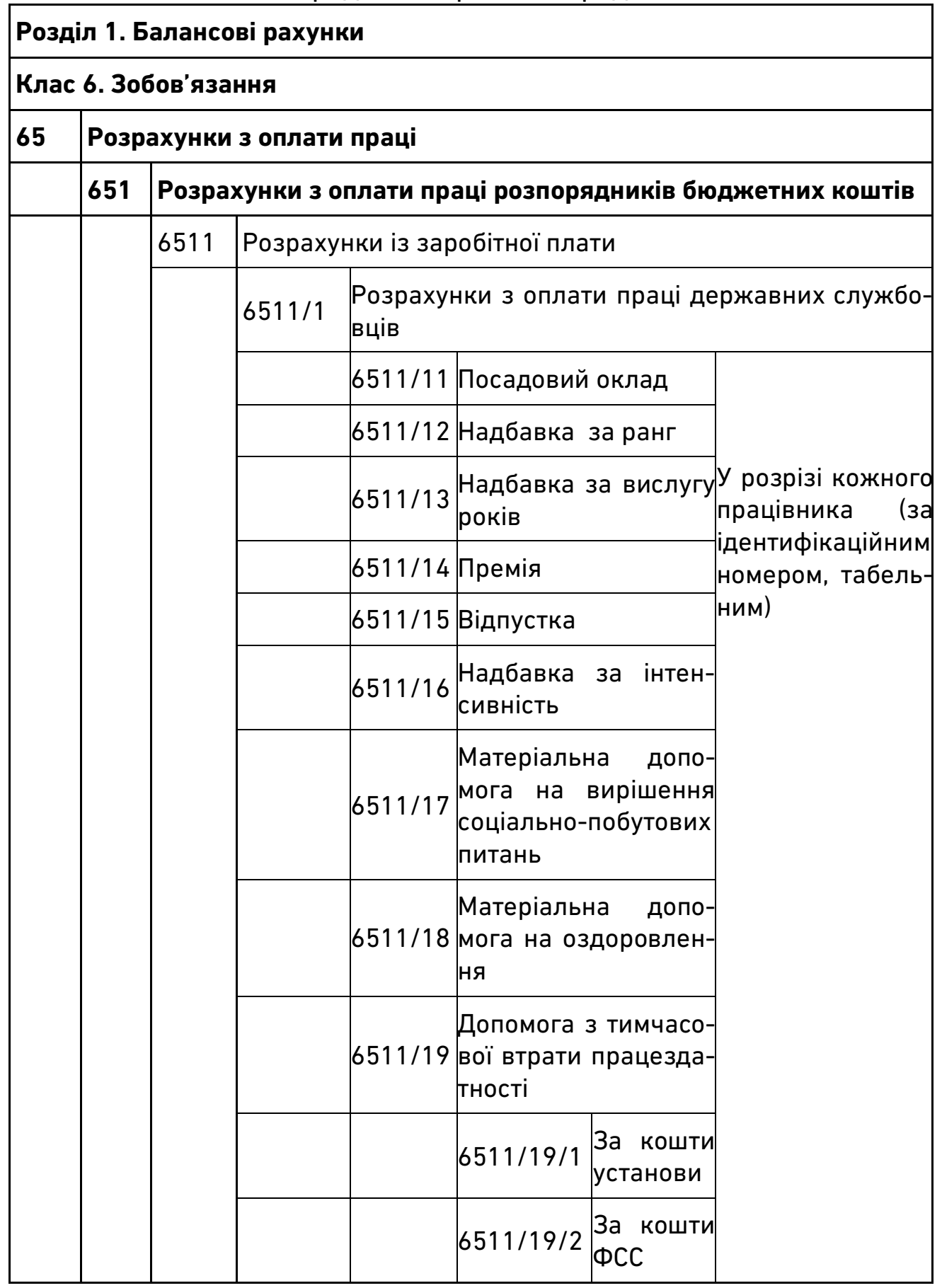


Приклад формату примітки може мати такий вигляд.

\section{Примітка щодо виплат працівникам}

\section{органу місцевого самоврядування}

\section{Рівень винагороди}

Працівники органів місцевого самоврядування отримують винагороду за свої професійні знання та послуги, які вони надають громаді. Рівень виплат залежить від виду діяльності, рівня знань та кількості витраченого часу. Допустимі суми виплат визначаються чинним законодавством. Основний принцип полягає в оплаті отриманих послуг за вартістю, що унеможливлює вчинення неналежного впливу на професіоналів у процесі прийняття ними рішень щодо надання послуг.

Розкриття інформації про виплати працівникам

\begin{tabular}{|c|c|c|}
\hline & $\begin{array}{l}\text { Категорії персо- } \\
\text { налу }\end{array}$ & Усього \\
\hline \multicolumn{3}{|l|}{ Посадовий оклад } \\
\hline \multicolumn{3}{|l|}{ Надбавка за вислугу років } \\
\hline \multicolumn{3}{|l|}{$\begin{array}{l}\text { Надбавка за ранг службовця місцевого } \\
\text { самоврядування }\end{array}$} \\
\hline \multicolumn{3}{|l|}{$\begin{array}{l}\text { Виплати за додаткове навантаження у } \\
\text { зв'язку з виконанням обов'язків тимча- } \\
\text { сово відсутнього службовця місцевого } \\
\text { самоврядування }\end{array}$} \\
\hline \multicolumn{3}{|l|}{$\begin{array}{l}\text { Виплати за додаткове навантаження у } \\
\text { зв'язку з виконанням обов'язків за вака- } \\
\text { нтною посадою службовця місцевого са- } \\
\text { моврядування }\end{array}$} \\
\hline \multicolumn{3}{|l|}{ Оплата відпусток } \\
\hline \multicolumn{3}{|l|}{ Премії } \\
\hline \multicolumn{3}{|l|}{ Інші заохочувальні виплати } \\
\hline $\begin{array}{l}\text { Матеріальна допомога для вирішення со- } \\
\text { ціально-побутових питань }\end{array}$ & & \\
\hline
\end{tabular}

Складено авторами

Висновки. Комплексне реформування управління державними фінансами, та системи оплати праці, як його частини, потребує відповідного інформаційного супроводу, який забезпечується бухгалтерським обліком. Кінцевим результатом реформування $\epsilon$ створення підстав для забезпечення прозорої роботи органів місцевого самоврядування, їх підзвітності та сприяння ефективному використанню 
публічних коштів. Громадськість повинна мати інформацію про стан просування реформ, у тому числі щодо виплат працівникам органів місцевого самоврядування. Тому сучасна фінансова звітність має включати примітки щодо виплат працівникам не тільки у розрізі, зазначеному в НП(С)БОДС 132, тобто про суми заборгованості за заробітною платою та суми виплат при звільненні, а й у розрізі складових виплат працівникам та категорій персоналу. Така інформація дозволить проаналізувати співвідношення між посадовим окладом та стимулюючими виплатами, ініціювати зміну складу та кількості працівників та інші рішення стосовно ефективного використання бюджетних кошів.

1. Моніторинг процесу децентралізації влади та реформування місцевого самоврядування станом на 10 листопада 2018 року : аналітична записка Міністерства регіонального розвитку, будівництва та житловокомунального господарства України. URL: https://storage. decentralization.gov.ua/uploads/library/file/333/10.11.2018.pdf (дата звернення: 15.11.2018). 2. Реформа оплати праці державних службовців : аналітична записка Центру економічної стратегії від 18.05.2017 p. URL: ces.org.ua (дата звернення: 15.11.2018). 3. Виплати працівникам : Міжнародний стандарт бухгалтерського обліку в державному секторі 25. URL: 195.78.68.18/minfin/ document/265674/25_final.pdf (дата звернення: 15.11.2018). 4. Лень В. С., Штупун М. П. Виплати працівникам : поняття, структура та облік. Проблеми і перспективи економіки та управління. 2015. № 2(2). С. 266-274. 5. Про місцеве самоврядування в Україні : Закон України від 21 травня 1997 року № 280/97-BP (в редакції від 01.01.2019 року). URL: https://zakon.rada.gov.ua/laws/show/280/97-\%D0\%B2\%D1\%80 (дата звернення: 15.11.2018). 6. Про державну службу : Закон України від 10.12.2015 p. № 889-VIII (зі змінами та доповненнями). URL: http://zakon.rada.gov.ua/ laws/show/889-19 (дата звернення: 15.11.2018). 7. Про доступ до публічної інформації : Закон України від 13 січня 2011 року № 2939-VI (в редакції від 01.05.2015 року). URL: https://zakon.rada.gov.ua/laws/show/2939-17 (дата звернення: 15.11.2018). 8. Про запобігання та протидію корупції : Закон України від 14 жовтня 2014 року № 1700-VII (в редакції від 31.08.2018 року). URL: https://zakon.rada.gov.ua/laws/show/1700-18 (дата звернення: 15.11.2018). 9. Про службу в органах місцевого самоврядування : проект Закону України № 2489. URL: http://w1.c1.rada.gov.ua/pls/zweb2/ webproc4_1?pf3511=64016 (дата звернення: 15.11.2018).

\section{REFERENCES:}

1. Monitorynh protsesu detsentralizatsii vlady ta reformuvannia mistsevoho samovriaduvannia stanom na 10 lystopada 2018 roku : analitychna zapyska Ministerstva rehionalnoho rozvytku, budivnytstva ta zhytlovo-komunalnoho 
hospodarstva

Ukrainy.

URL:

https://storage.

decentralization.gov.ua/uploads/library/file/333/10.11.2018.pdf (data zvernennia: 15.11.2018). 2. Reforma oplaty pratsi derzhavnykh sluzhbovtsiv : analitychna zapyska Tsentru ekonomichnoi stratehii vid 18.05.2017 r. URL: ces.org.ua (data zvernennia: 15.11.2018). 3. Vyplaty pratsivnykam : Mizhnarodnyi standart bukhhal-terskoho obliku $v$ derzhavnomu sektori 25. URL: 195.78.68.18/minfin/ document/265674/25_final.pdf (data zvernennia: 15.11.2018). 4. Len V. S., Shtupun M. P. Vyplaty pratsivnykam : poniattia, struktura ta oblik. Problemy i perspektyvy ekonomiky ta upravlinnia. 2015. № 2(2). S. 266-274. 5. Pro mistseve samovriaduvannia v Ukraini : Zakon Ukrainy vid 21 travnia 1997 roku № 280/97-VR (v redaktsii vid 01.01.2019 roku). URL: https://zakon.rada.gov.ua/laws/show/280/97-\%D0\%B2\%D1\%80 (data zver-nennia: 15.11.2018). 6. Pro derzhavnu sluzhbu : Zakon Ukrainy vid 10.12.2015 r. № 889-VIII (zi zminamy ta dopovnenniamy). URL: http://zakon.rada.gov.ua/ laws/show/889-19 (data zvernennia: 15.11.2018). 7. Pro dostup do publichnoi informatsii : Zakon Ukrainy vid 13 sichnia 2011 roku № 2939-VI (v redaktsii vid 01.05.2015 roku). URL: https://zakon.rada.gov.ua/laws/show/2939-17 (data zvernennia: 15.11.2018). 8. Pro zapobihannia ta protydiiu koruptsii : Zakon Ukrainy vid 14 zhovtnia 2014 roku № 1700-VII (v redaktsii vid 31.08.2018 roku). URL: https://zakon.rada.gov.ua/laws/show/1700-18 (data zvernennia: 15.11.2018). 9. Pro sluzhbu $v$ orhanakh mistsevoho samovriaduvannia : proekt Zakonu Ukrainy № 2489. URL: http://w1.c1.rada.gov.ua/pls/zweb2/ webproc4_1?pf3511=64016 (data zvernennia: 15.11.2018).

Рецензент: д.е.н., професор Савіна Н. Б. (НУВГП)

Zubilevych S. Y., Candidate of Economics (Ph.D.), Professor (National University of Water and Environmental Engineering, Rivne),

Pidhrushnyi V. A., Senior Student (National University of Water and Environmental Engineering, Rivne)

\section{DISCLOSURE OF INFORMATION ON EMPLOYEE BENEFITS OF THE LOCAL GOVERNMENT ENTITY IN THE CONTEXT OF STATE FINANCE DECENTRALIZATION}

The definition of employee benefits as an object of accounting and financial reporting at the current stage of reforming public administration is clarified based on the study of the categorical apparatus of the current legislation, national and international accounting standards, the views of scientists on the nature and functions of these expenses. The approach to deepening the analytical accounting of employee benefits as the most material item of 
expenses of public sector entities, taking into account the needs of the management of the local self-government body and public accountability, is proposed. At the same time, suggestions on improving the analitycal accounting of obligations for employee is substantiated. The standard chart of accounts is supplemented on the basis of the considered features of the classifications.

Recommendations for employee benefits disclosure in financial statements have been developed. All this will improve the quality of information that will be provided to both internal and external users for decision making.

Keywords: employee benefits, public finance management, decentralization, public sector entities, accounting, financial statements.

Зубилевич С. Я., к.э.н., профессор, Подгрушный В. А., студент (Национальный университет водного хозяйства и природопользования, г. Ровно)

\section{РАСКРЫТИЕ ИНФОРМАЦИИ О ВЫПЛАТАХ РАБОТНИКАМ ОРГАНОВ МЕСТНОГО САМОУПРАВЛЕНИЯ В КОНТЕКСТЕ ДЕЦЕНТРАЛИЗАЦИИ ГОСУДАРСТВЕННЫХ ФИНАНСОВ}

На основании исследования категориального аппарата действующего законодательства, национальных и международных стандартов бухгалтерского учета, точек зрения ученых о сущности и функциях уточнено определение выплат работникам как объекта учета и финансовой отчетности на современном этапе реформирования государственного управления. Предложен подход к углублению аналитики учета выплат работникам как наиболее весомой статьи расходов субъектов государственного сектора с учетом потребностей управления органом местного самоуправления и подотчетности общественности. Одновременно обоснованы предложения по совершенствованию аналитики учета обязательств по выплатам работникам. Дополнен типовой план счетов бухгалтерского учета для отражения операций по выплатам работникам. Разработаны рекомендации по раскрытию выплат работникам в финансовой отчетности, которые повысят качество информации, предоставляемой внутренним и внешним пользователям.

Ключевые слова: выплаты работникам, управление государственными финансами, децентрализация, субъекты государственного сектора, бухгалтерский учет, финансовая отчетность. 